\title{
Comparative Field Efficacy of Management Strategies Containing Brassica napus Seed Meal or Green Manure for the Control of Apple Replant Disease
}

\author{
Mark Mazzola, United States Department of Agriculture-Agricultural Research Service, Tree Fruit Research Labo- \\ ratory, Wenatchee, WA 98801; and Kent Mullinix, Department of Horticulture and Landscape Architecture, Wash- \\ ington State University, Wenatchee 98801
}

\begin{abstract}
Mazzola, M., and Mullinix, K. 2005. Comparative field efficacy of management strategies containing Brassica napus seed meal or green manure for the control of apple replant disease. Plant Dis. 89:1207-1213.

Alternative management strategies to the use of preplant soil fumigation for the control of apple replant disease (ARD), including cover crops and strategies incorporating Brassica napus seed meal (rape seed meal [RSM]) amendment as the central component, were evaluated in the orchard. A 1-year wheat cover crop consisting of three short-term cropping periods with plant material removed at the end of each growth period and a 3-year B. napus green manure significantly enhanced vegetative growth and yield of Gala/M26. However, in each instance, the resulting disease control and growth response were inferior to that achieved through preplant methyl bromide soil fumigation. A 3-year bare fallow and 1- or 2-year B. napus green manure neither suppressed disease development nor enhanced tree growth. Preplant RSM amendment in conjunction with a postplant mefenoxam soil drench provided effective suppression of ARD, and the resulting tree growth and yield were comparable with that attained in response to 1,3dichloropropene-chloropicrin fumigation in one orchard. At a second orchard, the growth response attained with the alternative treatment was inferior to preplant soil fumigation, which was associated with an apparent re-infestation of RSM-treated soils and tree roots by Pratylenchus spp. Application of RSM after wheat cropping or in conjunction with soil solarization provided an intermediate level of disease control and a corresponding reduction in growth and yield of apple relative to preplant fumigation at both sites.
\end{abstract}

Apple replant disease (ARD) is widespread, having been documented in all of the major fruit-growing regions of the world (25), and is a significant impediment to the establishment of economically viable orchards on sites previously planted to apple. Replant diseases of fruit trees typically have been controlled through preplant application of broad-spectrum soil sterilants (11), all of which possess potential health or environmental risks. The development of more targeted approaches to the management of this disease has been impeded by the large number of biotic and abiotic factors which have been reported as possible causal agents (25). Likewise, the supposition that the etiology of the disease varies considerably from site to site also has contributed to the lack of progress

Corresponding author: M. Mazzola

E-mail: mazzola@tfrl.ars.usda.gov

This research was supported in part by funds from the USDA-ARS, USDA-CSREES grants program agreement 98-34103-6414, and the Washington Tree Fruit Research Commission.

Accepted for publication 23 June 2005.

DOI: 10.1094/PD-89-1207

This article is in the public domain and not copyrightable. It may be freely reprinted with customary crediting of the source. The American Phytopathological Society, 2005. toward developing effective nonfumigant control measures. The fact that soil pasteurization or fumigation $(5,11,23)$ dramatically improves the growth of apple in orchard replant soils provides evidence that the disease is primarily a biological phenomenon rather than the direct result of abiotic factors. Studies conducted in Washington state demonstrated that the primary etiologic agents, which vary in relative dominance from site to site, include fungi of the genera Cylindrocarpon, Phytophthora, Pythium, and Rhizoctonia, at times acting in conjunction with lesion nematodes, Pratylenchus spp. (14).

Previous work demonstrated that the genetic and functional composition of the fluorescent pseudomonad population can be manipulated effectively in orchard soils $(7,18)$. In greenhouse studies, cropping orchard soils with specific wheat genotypes modified the species and genetic composition of this bacterial community. Soils cropped with specific wheat cultivars possess a fluorescent Pseudomonas spp. community with a higher proportion of strains capable of producing the antifungal metabolite 2,4-diacetylphloroglucinol (16) and exhibit a significantly higher level of antagonism toward Rhizoctonia solani (18). These soils were correspondingly suppressive to Rhizoctonia root rot $(7,18)$. This cropping practice also was associated with a reduction in recovery of Pythium and Pratylenchus spp. and superior growth of apple subsequently planted into these wheat-cropped orchard soils $(7,17,18)$. In microplot studies, rotation with wheat cv. Penewawa, a cultivar which, when cropped in replant soils, enhanced subsequent growth of apple $(17,18)$, was shown to improve growth of peach in orchard replant soils (3).

Biologically based soil treatments such as the use of organic residue amendments also offer realistic alternatives to broadspectrum biocides for the management of soilborne plant pathogens. Bioactive plant products, introduced either as a green manure crop or soil amendment, have been promoted within the organic farming community as a practice for the control of soilborne diseases. Members of the plant family Brassicaceae, including Brassica napus, produce glucosinolates which, upon hydrolysis, yield biologically active compounds, including isothiocyanates $(1,2)$. Isothiocyanates have a broad spectrum of antimicrobial activity; therefore, investigators have focused on the use of these plants as "biofumigants", where incorporation of plant residue into soil ultimately results in release of the active hydrolysis products $(1,2)$. However, a growing body of evidence suggests that some of these plant residues may operate in the suppression of fungal pathogens via a different, as yet unidentified, mechanism. For example, reports exist of the potential of B. napus residues to control soilborne plant pathogens $(1,16)$, though separate reports suggest that these plant residues yield isothiocyanates having relatively low antimicrobial activity (12). Likewise, the protective effect of Brassicaceae residues against fungal infection of pea plants was found to increase for weeks after isothiocyanates had been lost from the soil either by volatilization or microbial degradation $(10,19,28)$.

In a more direct study, we have demonstrated that the suppression of certain apple root pathogens and parasites, including $R$. solani and Pratylenchus penetrans, was obtained via the incorporation of B. napus seed meal (rape seed meal [RSM]) irrespective of the glucosinolate content of the amendment $(4,16)$. RSM is highly suppressive toward disease incited by $R$. solani AG-5 on apple, provided that a 3- to 4week fallow period is provided prior to planting (16). We have reported that appli- 
cation of $1 \%$ (vol/vol) RSM completely eliminated $R$. solani AG-5 infection of apple seedlings whereas, root infection rates ranged from 6.1 to $28.5 \%$ in the same nontreated orchard soils.

The goal of this project was to integrate control methods previously identified in greenhouse studies in a biologically rational and horticulturally sound manner, and to evaluate the efficacy of cover crops and strategies incorporating RSM amendment as the central component for the potential as nonfumigant alternatives in the management of ARD.

\section{MATERIALS AND METHODS}

Field sites. Studies were conducted at the Columbia View Research (CV) Orchard near Orondo, WA and the Wenatchee Valley College-Auvil Research and Demonstration (WVC) orchard, East Wenatchee, WA. The dominant soil types at the CV and WVC orchards are Burch sandy loam and Pogue fine sandy loam, respectively. The biological elements contributing to disease development at the $\mathrm{CV}$ solani AG-5 and AG-6, Pythium heterothallicum, $P$. intermedium, Phytophthora cactorum, and Cylindrocarpon destructans are primary pathogens at the $\mathrm{CV}$ orchard. $R$. solani AG-5, binucleate Rhizoctonia $\mathrm{sp.}$ AG-I, Pythium sylvaticum, P. ultimum, Phytophthora cactorum, C. destructans, and the lesion nematode, Pratylenchus spp., are the primary biological agents inciting replant disease at the WVC orchard.

Impact of cover cropping on apple growth and yield at CV orchard. Tree removal and subsequent establishment of treatments was conducted using a randomized complete block design on orchard ground previously planted to Malus domestica cv. Delicious on seedling rootstock. The orchard block was 27 years old at the time of initial tree removal in September 1997. Portions of the orchard block orchard have been described (13-15). $R$.

were removed sequentially in September 1997, 1998, and 1999. Initial planting of green manure crop treatments to a specific plot occurred in the spring of the year subsequent to tree removal (29 May 1998 or 12 May 1999) or immediately after tree removal (14 September 1999). The treatments applied in this study are listed in Table 1; each treatment was represented by three replications. Seed beds were prepared for planting by cultivating soils using a rotovator to a depth of 15 to $20 \mathrm{~cm}$. Rape (Brassica napus cv. Dwarf Essex) was planted using a single-row planter, with seed rows sown at $10-\mathrm{cm}$ spacing. Seed were planted at a depth of $2 \mathrm{~cm}$ at a rate of $27.45 \mathrm{~kg} \mathrm{ha}^{-1}$ and the crop was grown under irrigation. Impact sprinklers were employed and plots were watered twice weekly for a period of $8 \mathrm{~h}$. Plots were assayed to determine biomass production just prior to incorporation of plant matter into the soil profile by cultivation in September for plantings established in May 1998 and 1999, and 9 May 2000 for the planting established in September 1999. These orchard parcels were replanted at the times stated above, resulting in plots receiving one, two, or three rape green manure crops prior to planting the site to apple. In addition to cover crop treatments, a 3-year bare fallow treatment was maintained through periodic application of glyphosphate to three randomly selected plots from which trees were removed in September 1997.

Wheat was planted on 2 May 1999 in those plots from which trees had been removed in September 1998, or plots which had been planted to B. napus during the two preceding years. Wheat (Triticum aestivum) was planted as a seed mixture of the soft white winter wheat cvs. Daws, Lewjain, and Sprague (1:1:1). All seed used in these studies were obtained from the Washington State Crop Improvement Association, Foundation Seed Service, Washington State University, Pullman.

Table 1. Effect of cover cropping on cumulative tree growth and fruit yield from Gala/M26 apple planted in May 2000 at the Columbia View Research orchard, Orondo, WA ${ }^{\mathrm{y}}$

\begin{tabular}{lcccc}
\hline Treatment & $\begin{array}{c}\text { 2000 diam. } \\
\text { inc. }(\mathbf{m m})\end{array}$ & $\begin{array}{c}\text { 2001 diam. } \\
\text { inc. }(\mathbf{m m})\end{array}$ & $\begin{array}{c}\text { 2002 yield } \\
\left(\mathbf{k g ~ t r e e}^{-\mathbf{1}}\right)\end{array}$ & $\begin{array}{c}\text { 2003 yield } \\
\left(\mathbf{k g ~ t r e e}^{-\mathbf{1}}\right)\end{array}$ \\
\hline Control & $0.79 \mathrm{c}$ & $6.61 \mathrm{c}$ & $2.01 \mathrm{c}$ & $3.10 \mathrm{~d}$ \\
Methyl bromide & $5.61 \mathrm{a}$ & $18.14 \mathrm{a}$ & $9.14 \mathrm{a}$ & $10.53 \mathrm{a}$ \\
3-year fallow & $1.14 \mathrm{c}$ & $7.25 \mathrm{c}$ & $1.89 \mathrm{c}$ & $4.03 \mathrm{~cd}$ \\
1-year wheat & $2.91 \mathrm{~b}$ & $10.33 \mathrm{~b}$ & $3.98 \mathrm{~b}$ & $5.35 \mathrm{bc}$ \\
1-year rape seed & $1.02 \mathrm{c}$ & $8.88 \mathrm{bc}$ & $2.08 \mathrm{c}$ & $4.64 \mathrm{bcd}$ \\
2-year rape seed & $1.37 \mathrm{c}$ & $8.84 \mathrm{bc}$ & $1.79 \mathrm{c}$ & $5.54 \mathrm{bc}$ \\
3-year rape seed & $3.20 \mathrm{~b}$ & $11.76 \mathrm{~b}$ & $2.87 \mathrm{bc}$ & $6.52 \mathrm{~b}$ \\
2-year rape seed, 1-year wheat & $2.86 \mathrm{~b}$ & $9.78 \mathrm{~b}$ & $3.68 \mathrm{~b}$ & $5.69 \mathrm{bc}$ \\
$P$ & 0.013 & $<0.001$ & 0.003 & $<0.001$ \\
\hline
\end{tabular}

y Tree trunk diameters were measured in September of the specified year; diam. inc. = diameter increase. Values in the same column followed by the same letter are not significantly different according to the Tukey test $(P=0.05)$.

z Study was conducted using a randomized complete block design with three replicates, each consisting of eight trees. Trees from the previous orchard were removed in September 1, 2, or 3 years prior to planting apple, which corresponds to the total number of crop years as indicated in the respective treatments. Control and methyl bromide fumigation treatments were established in plots from which trees were removed in September 1999.
Cultivars were selected based upon studies which examined growth of Gala apple seedlings in orchard replant soils that had been precropped with wheat (7). Seed were sown as above using a row spacing of $12.5 \mathrm{~cm}$ at a seeding rate of $140.5 \mathrm{~kg} \mathrm{ha}^{-1}$, and the crop was grown under irrigation. Wheat was allowed to grow for approximately 9 weeks and then was mowed, with plant biomass removed prior to cultivation and replanting in July and again in September. The final wheat crop was removed in May 2000 after perennation.

Methyl bromide soil fumigation was conducted on 16 September 1999 in designated plots from which trees were removed during the same year. The site was cultivated and tarped prior to injection of Brom-O-Gas (Great Lakes Chemical Corporation, West Lafayette, IN) at a rate of $0.05 \mathrm{~kg} / \mathrm{m}^{2}$. Plots from which trees were removed in September 1999 and which received no additional treatment served as the control. The orchard (all treatments) was planted on 18 May 2000 with Gala/M26 apple using 1-m spacing between trees within a row and $3.5-\mathrm{m}$ spacing between rows. The experiment utilized a randomized complete block design consisting of three replicates, each comprising eight trees.

Impact of $B$. napus seed meal on growth of apple on replant sites. Studies were conducted at the CV and WVC orchards to assess the utility of B. napus seed meal amendment in conjunction with a pre-amendment wheat cropping, postamendment solarization, or postplant application of mefenoxam (Ridomil Gold EC; Syngenta, Greensboro, NC) soil drench for the management of replant disease. The RSM-mefenoxam treatment was included in these studies due to the observation that RSM amendment results in significant increases in resident soil populations of Pythium spp. and a concomitant increase in apple root infection $(7,16)$. The $B$. napus seed meal (Montana Vegetable Oils, Great Falls, MT) used in these studies possessed a low total glucosinolate

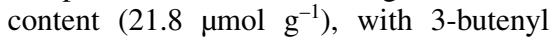
glucosinolate being dominant, and $6 \%$ total N. RSM was applied 22 May 2001 at a rate of $8533 \mathrm{~kg} \mathrm{ha}^{-1}$ and incorporated into soil to a depth of $15-20 \mathrm{~cm}$. Clear plastic, $152 \mu \mathrm{m}$ thick (Sunbelt Plastics, Monroe, LA) was applied on the same date to plots receiving the solarization and solarization plus RSM treatment, with the solarization alone treatment being applied only at the WVC orchard. Soil temperature under plastic was monitored with a WatchDog Data Logger (Spectrum Technologies, Inc., Plainfield, IL) during June 2001 at a depth of $25 \mathrm{~cm}$, with one probe in the center of each solarized plot. For the wheat followed by RSM amendment treatment, plots were planted with 'Penawawa' spring wheat on 3 May 2001 using the same method and seeding rate as de- 
scribed above. Plant biomass was removed on 20 September, and RSM was applied and plots were rotovated as above on 3 April 2002. Preplant application of the soil fumigant 1,3-dichloropropene-chloropicrin (Telone C17; DowElanco, Indianapolis, IN) was conducted on 20 September 2001 by a commercial applicator at a rate of 282 liters $\mathrm{ha}^{-1}$. Control and fumigated plots were fertilized with ammonium sulfate (34-0-0) at a rate of $184 \mathrm{~kg} \mathrm{ha}^{-1}$.

The WVC and CV orchards were planted to Golden Delicious/M7 and Gala/M26 on 9 April and 13 May 2002, respectively. Trees planted into RSMamended soils received a soil drench of diluted $\left(0.63 \mathrm{ml} \mathrm{liter}^{-1}\right)$ mefenoxam applied at the base of each tree on 19 April and 22 May 2002 at the WVC and CV orchard, respectively. Trees were grown under irrigation and standard orchard practices, including the maintenance of a weed-free under-tree strip (approximately $1.5 \mathrm{~m}$ wide) through intermittent use of glyphosphate herbicide and application of ammonium sulfate fertilizer (34-0-0) each autumn. Experiments were designed as a randomized complete block consisting of four replicates comprising eight trees each.

Root collection and microbial analysis. Root samples were collected from 4 arbitrarily selected trees in each 8-tree plot for a total of 12 and 16 sampled trees for each treatment in the plantings established in 2000 and 2002, respectively. Samples were collected in October of the planting year at $\mathrm{CV}$ orchard, and separate samples were collected in October 2002 and 2003 at the WVC site. The upper $5 \mathrm{~cm}$ of the soil surface was removed with a shovel and roots were collected at a depth of 5 to 20 $\mathrm{cm}$ at two opposing sides of the tree at a distance 20 to $40 \mathrm{~cm}$ from the tree base. The root samples were combined for an individual tree, placed in plastic bags, and stored at $4^{\circ} \mathrm{C}$. Assessment of nematode and fungal populations were conducted on root systems within 2 weeks of collection. Populations of lesion nematode (Pratylenchus spp.) resident in apple roots were determined for all root samples. The fungal population colonizing apple roots was determined for the samples harvested during October of the initial growing season.

For assessment of Pratylenchus populations, a $0.5-\mathrm{g}$ subsample was excised from each tree root system and individual samples were placed into 125 -ml flasks containing $80 \mathrm{ml}$ of sterile distilled water. Flasks were placed on a reciprocal shaker and incubated at $150 \mathrm{rpm}$ for 5 days. Nematodes were collected by passing the suspension twice through a 350-mesh sieve and backwashing into a counting dish, and Pratylenchus spp. were counted using a light microscope $(\times 40) \quad(14)$. Isolation and identification of fungi from apple roots was conducted as described previously (14).

Assessment of plant growth and yield. The effect of soil treatments on vegetative tree growth was determined by monitoring the increase in trunk diameter during the initial two or three growing seasons. Immediately after planting, trees were marked at a point approximately $0.7 \mathrm{~m}$ above the soil line with white latex paint and initial tree diameter was measured. Tree diameter was measured periodically over the course of three growing seasons. Measurements were obtained using an electronic caliper with two readings obtained at $90^{\circ}$ intervals to achieve an average trunk diameter for each tree. Harvest data from the $\mathrm{CV}$ orchard experiments were obtained beginning with initial fruit production, which occurred as early as the second growing season. Fruit were harvested from individual trees and weighed in the field. Yield data were not acquired from trees at the WVC site because economic conditions, management costs, and tree growth performance did not allow for carrying a crop to harvest.

Statistical analysis. Growth and yield data from an eight-tree plot served as the observational unit. Percent root infection data were transformed to arcsine-square root values prior to analysis. Root infection and nematode population data for a given plot served as the observational unit. Data were subjected to analysis of variance and mean separation using the Tukey test. Statistical analyses were conducted using Sigma-Stat (version 2.0; SPSS, San Rafael, CA).

\section{RESULTS}

Effect of cover crop systems on growth of apple in replant soil. Growth and yield of Gala/M26 established in methyl bromide-fumigated soils at the CV orchard in May 2000 was significantly enhanced relative to the control (Table 1). At the end of the initial growing season (September 2000), trees grown in soils that had been subjected to cropping sequences, including 1-year wheat (three successive plantings), 3-year rape green manure, and 2-year rape green manure followed by 1 year wheat cover crop each exhibited im- proved vegetative growth relative to the control; however, in each case, the growth response was inferior to that achieved through preplant soil fumigation with methyl bromide. A 3-year fallow period and a 1- or 2-year rape green manure crop (applied for 1 or 2 years, respectively, after tree removal) did not significantly improve tree growth. Relative increase in tree diameter was maintained during the second growing season for all treatments, and vegetative growth of trees established in fumigated soil continued to significantly outperform all other treatments (Table 1).

Initial fruit harvest from this orchard block was recorded during August 2002. Trees grown in soils that had been cropped to wheat for 1 year or rape seed for 2 years followed by a year of wheat provided significantly higher fruit yields than the control in 2002 and 2003. The fallow treatment and all rape seed-only treatments did not improve yield during 2002, but 2- and 3 -year rape seed green manure cropping significantly enhanced yield compared with the control in 2003. Fruit yields achieved from all fallow or cover-cropped blocks were significantly less than that attained from methyl bromide-fumigated blocks during both years.

Relative growth and yield achieved in response to preplant treatments were associated with suppression of root infection by the fungal incitants of replant disease at this site. Methyl bromide fumigation, treatments that included wheat cropping, and 3-year rape seed cover crop significantly reduced infection of apple roots by Rhizoctonia spp. (Table 2). Soil fumigation was the only treatment that significantly reduced subsequent infection of apple by C. destructans. Fusarium spp., which do not limit apple growth (14), were recovered repeatedly from apple roots, but the rate of recovery was not influenced by any soil treatment. Recovery of Pythium spp. from apple occurred consistently at a low frequency and the rate did not differ among treatments. Lesion nematode populations were below $25 \mathrm{~g}^{-1}$ of root for all

Table 2. Effect of cover cropping treatments on recovery (percentage of root segments analyzed) of fungi from roots of Gala/M26 planted in May 2000 at the Columbia View Research orchard, Orondo, WA

\begin{tabular}{lcccc}
\hline Treatment $^{z}$ & Cylindrocarpon & Fusarium & Pythium & Rhizoctonia \\
\hline Control & $41.9 \mathrm{a}$ & 23.1 & 3.1 & $20.0 \mathrm{a}$ \\
Methyl bromide & $8.7 \mathrm{~b}$ & 32.5 & 1.2 & $3.8 \mathrm{c}$ \\
3-year fallow & $28.8 \mathrm{a}$ & 31.3 & 3.8 & $18.8 \mathrm{a}$ \\
1-year wheat cover crop & $28.1 \mathrm{ab}$ & 30.6 & 1.3 & $1.3 \mathrm{c}$ \\
1-year rape green manure & $25.0 \mathrm{ab}$ & 35.0 & 2.5 & $16.3 \mathrm{a}$ \\
2-year rape green manure & $42.5 \mathrm{a}$ & 36.2 & 1.3 & $13.7 \mathrm{ab}$ \\
3-year rape green manure & $37.5 \mathrm{a}$ & 36.2 & 1.3 & $7.5 \mathrm{bc}$ \\
2-year rape green manure, 1-year wheat & $31.9 \mathrm{a}$ & 31.3 & 3.8 & $5.6 \mathrm{c}$ \\
$P$ & 0.002 & 0.589 & 0.820 & $<0.001$ \\
\hline
\end{tabular}

y Values in the same column followed by the same letter are not significantly different according to the Tukey test $(P=0.05)$.

${ }^{\mathrm{z}}$ Study was conducted using a randomized complete block design with three replicates, each consisting of eight trees. Trees from the previous orchard were removed in September 1, 2, or 3 years prior to planting apple, which corresponds to the total number of crop years as indicated in the respective treatments. Control and methyl bromide fumigation treatments were established in plots from which trees were removed in September 1999. 
soil treatments and were not significantly different from the control (data not shown).

Effect of RSM on growth of apple in replant soils. At completion of the third growing season (28 months post planting), significant differences in vegetative growth were observed among treatments at the $\mathrm{CV}$ $(P<0.001)$ and WVC $(P<0.001)$ orchards. RSM soil amendment used in conjunction with a postplant application of mefenoxam resulted in a significant $(P<$ $0.05)$ improvement in growth of Gala/M26 and Golden Delicious/M7 relative to the nontreated control at the $\mathrm{CV}$ and WVC orchards, respectively. At the CV orchard, trees planted in the RSM-mefenoxamtreated plots grew as well as trees grown in

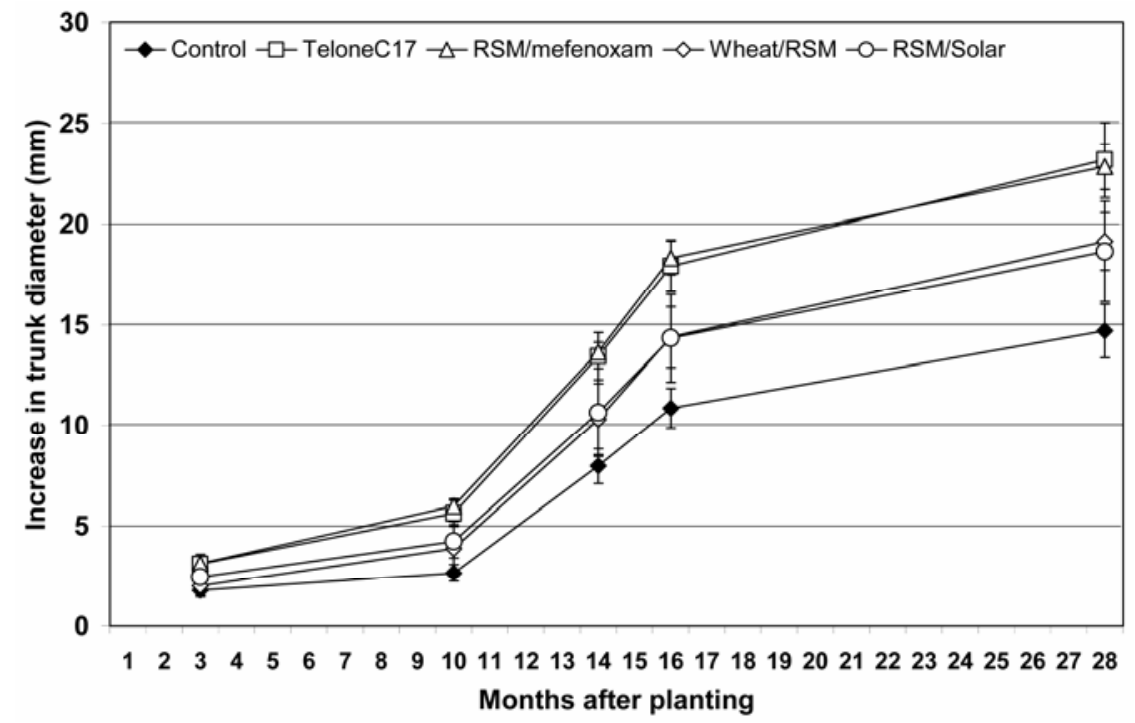

Fig. 1. Impact of soil treatments on increase in trunk diameter for Gala/M26 over three growing seasons at the Columbia View Research orchard, Orondo, WA. Values are means ( \pm standard deviation) of four replicates, each consisting of eight trees.

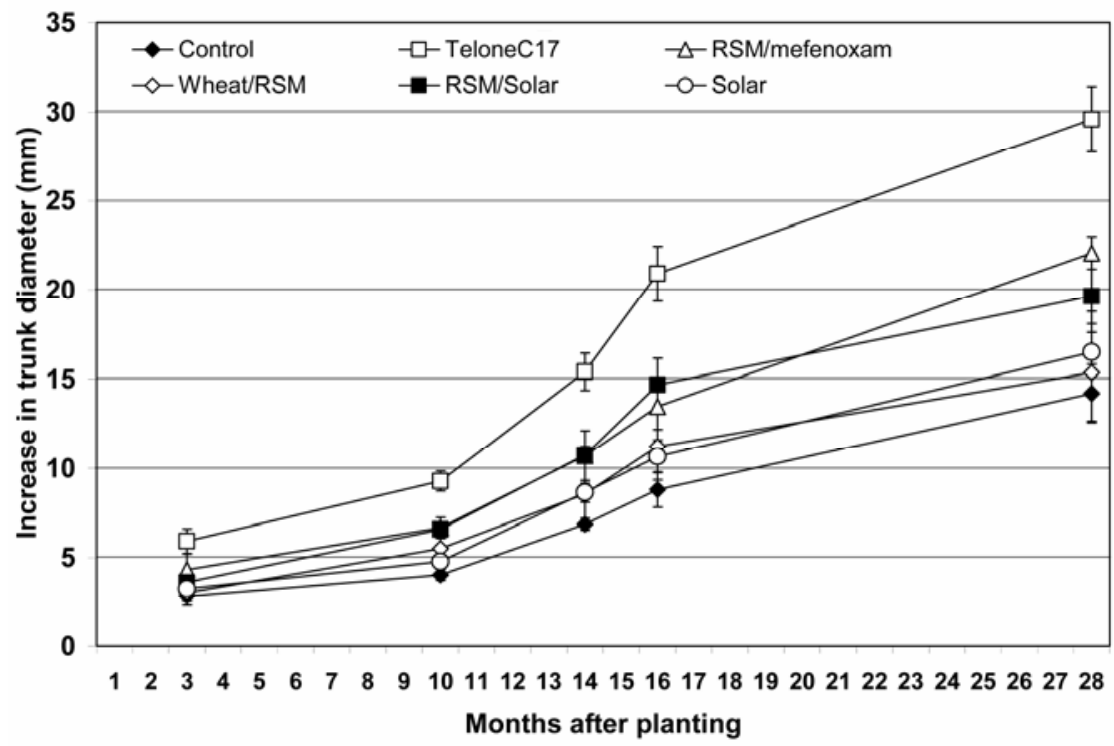

Fig. 2. Impact of soil treatments on increase in trunk diameter of Golden Delicious/M7 over three growing seasons at the Wenatchee Valley College-Auvil Research and Demonstration orchard, East Wenatchee, WA. Values are means ( \pm standard deviation) of four replicates, each consisting of eight trees. soil fumigation clearly was superior to all other soil treatments in promoting tree growth at this site. By the end of the third growing season, increase in trunk diameter for trees planted in wheat-RSM-treated or -solarized soil was not significantly different from the nontreated control.

Initial fruit yields were acquired from the $\mathrm{CV}$ orchard during the second growing season (2003), with noteworthy quantities of fruit being obtained only from trees established in RSM-mefenoxam-treated soils (Table 3). During 2004, yields obtained from the RSM-solar and wheatRSM treatments were significantly greater than the nontreated control, but less than that of trees grown in 1,3-dichloropropenechloropicrin and RSM-mefenoxam-treated soils. Yields obtained from the fumigated and RSM-mefenoxam-treated blocks during 2004 were equivalent.

Enhanced tree growth and yield were associated with suppression of plantpathogenic and parasitic organisms at both orchard sites. Soil fumigation with 1,3dichloropropene-chloropicrin effectively reduced infection by the fungal root pathogens $C$. destructans, Pythium spp., and Rhizoctonia spp. (Table 4). RSM amendment in combination with mefenoxam, solarization, or wheat cropping, and solarization alone all significantly decreased recovery of Rhizoctonia spp. from apple roots. RSM amendments suppressed infection by $C$. destructans when applied in conjunction or combination with mefenoxam or solarization. However, when soils were cropped to wheat prior to application of RSM, the efficacy of the amendment against this fungal pathogen appeared to be diminished at both sites. Infection by Pythium spp. was effectively suppressed by the RSM-mefenoxam treatment at both sites, but was not reduced at the CV site in response to RSM-solar or wheat-RSM sequences. Apple root infection by Pythium spp. was demonstrably lower for the RSM-solar, wheat-RSM, and solarization treatments at WVC.

Although lesion nematode populations were low at the CV site, all soil treatments significantly lowered recovery of Pratylenchus spp. from roots of Gala/M26 relative to the control. Similarly, except for solarization alone, all treatments significantly reduced initial recovery of lesion nematode from roots of Golden Delicious/M7 at the WVC orchard. With the exception of 1,3-dichloropropene-chloropicrin fumigation, nematode suppression was not maintained beyond the first growing season and, by the end of the second year of tree growth, root populations of Pratylenchus spp. had increased, often to a level equivalent to or greater than the control (Table 5).

\section{DISCUSSION}

Methods evaluated in these studies were formulated based upon results obtained in 
previous greenhouse trials which demonstrated their potential as an alternative to the use of preplant soil fumigation for the management of ARD $(7,16,17)$. Certain practices, which previously exhibited control of specific pathogens in the greenhouse, such as cropping wheat, do not appear to be suitable means for management of this disease syndrome as applied in this study. A year-long cover crop of wheat significantly enhanced growth and yield at the CV orchard; however, disease control was not sufficient to attain a level of productivity comparable to that achieved through the application of preplant soil fumigation. Cylindrocarpon spp., an important apple root rot pathogen at this site, was not suppressed in greenhouse trials (17), nor was it diminished by wheat cropping in the current study. In addition, at a soil depth of 5 to $20 \mathrm{~cm}$ by Rhizoctonia spp. was suppressed, based upon wheat growth patterns in the field, it is plausible that infection of roots at greater soil depth was not altered. Root-induced modification of resident fluorescent Pseudomonas spp. populations appears to function in the suppression of Rhizoctonia root rot observed in response to wheat cropping $(7,17,18)$. Although establishment of wheat stands in a greenhouse growing environment resulted in the development of a dense root system through soil, in field trials, the wheat root system was confined to the upper $25 \mathrm{~cm}$ of the soil profile (data not although infection of apple roots recovered

shown). Rooting depth likely was minimized due to the short-term cycling of wheat employed in these studies. Such a cropping sequence was predicated upon the correlation between wheat cycling and the resulting transformation in fluorescent pseudomonad populations that is associated with disease control (18).

An extended fallow period between successive plantings of the same crop species has been used successfully as a means to control soilborne plant diseases in certain annual cropping systems (6). However, in perennial cropping systems, the use of fallow periods has not consistently demonstrated the capacity to enhance plant growth when the same crop was subsequently established in these soils $(3,26)$ or suppress the activity of potential rootparasitic organisms (22). Compared with the control, a 3-year fallow period employed in this study did not reduce recovery of the major fungal pathogens resident to the $\mathrm{CV}$ orchard from the roots of Gala/M26. Correspondingly, there was no significant increase in plant growth or yield of apple in response to the 3-year bare fallow treatment. These data clearly indicated that the use of such a strategy for the control of ARD is not warranted.

The incorporation of brassica green manures in disease management programs has received significant consideration due to the perception that these organic materials possess the capacity to actively suppress plant pathogens and parasites through the

Table 3. Mean fruit yields $\left(\mathrm{kg} \mathrm{tree}^{-1}\right)$ from Gala/M26 apple established at the Columbia View Research orchard, Orondo, WA in May $2002^{y}$

\begin{tabular}{lcc}
\hline Treatment $^{\mathbf{z}}$ & $\mathbf{2 0 0 3}$ & $\mathbf{2 0 0 4}$ \\
\hline Control & $0.0 \mathrm{c}$ & $5.67 \mathrm{c}$ \\
1,3-dichloropropene-chloropicrin & $0.37 \mathrm{~b}$ & $13.29 \mathrm{a}$ \\
RSM-mefenoxam & $1.32 \mathrm{a}$ & $13.40 \mathrm{a}$ \\
RSM-solarization & $0.19 \mathrm{bc}$ & $8.46 \mathrm{~b}$ \\
Wheat-RSM & $0.11 \mathrm{bc}$ & $8.98 \mathrm{~b}$ \\
$P$ & $<0.001$ & $<0.001$ \\
\hline
\end{tabular}

${ }^{y}$ Study was conducted using a randomized complete block design with four replicates, each consisting of eight trees. Values in the same column followed by the same letter are not significantly different according to the Tukey test $(P=0.05)$.

${ }^{\mathrm{z}} \mathrm{RSM}=$ Brassica napus seed meal. release of glucosinolate hydrolysis products $(1,2,21)$. However, in certain instances, brassicaceous plant residues have been shown to provide disease control regardless of glucosinolate content (16) or to be no more effective than a fallow period or non-Brassica break crops for control of soilborne diseases in annual cropping systems $(6,8,24)$. In our studies, a 1or 2-year B. napus green manure crop had little or no impact on disease development and plant growth and yield. A 3-year rape green manure crop significantly diminished root infection by Rhizoctonia spp. and enhanced yield relative to the control in 2003, the fourth orchard growing season. However, as was found with the cropping of wheat for a period of 1 year, the growth response achieved was inferior to preplant soil fumigation with methyl bromide and resulting yields did not approach those likely to be necessary for adoption of this alternative by commercial producers.

Among treatments evaluated in these trials, those that incorporated a lowglucosinolate-content $B$. napus seed meal as a component were the most effective nonfumigant methods in controlling ARD and enhancing fruit yields. At the CV orchard, RSM-mefenoxam treatment was as effective as preplant soil fumigation with 1,3-dichloropropene-chloropicrin in controlling the agents that incite ARD. This treatment provided a growth and yield response which corresponded with disease suppression and was equivalent to that attained through preplant fumigation. The wheat-RSM and RSM-solarization treatments resulted in incomplete disease control, with no suppression or a substantial increase in Pythium spp. root infection at the $\mathrm{CV}$ site, and a corresponding yield that was intermediate between that attained in the control and fumigated soils. The RSMsolarization and wheat-RSM treatments unexpectedly did not exacerbate Pythium spp. root infection at the WVC site. The differential response in Pythium spp. root infection at the two sites may have resulted from differences in the dominant Pythium sp. at the CV ( $P$. heterothallicum and $P$.

Table 4. Effect of preplant soil treatments on recovery (percentage of root segments analyzed) of dominant fungi from roots of Gala/M26 and Golden Delicious/M7 apple at the Columbia View Research (CV) orchard Orondo, WA and Wenatchee Valley College-Auvil Research and Demonstration (WVC) Orchard East. Wenatchee, WA, respectively ${ }^{\mathrm{x}}$

\begin{tabular}{|c|c|c|c|c|c|c|c|c|}
\hline \multirow[b]{2}{*}{ Treatment $^{y}$} & \multicolumn{4}{|c|}{ CV orchard } & \multicolumn{4}{|c|}{ WVC orchard } \\
\hline & $\begin{array}{c}\text { Cylindrocarpon } \\
\text { destructans }\end{array}$ & $\begin{array}{c}\text { Fusarium } \\
\text { spp. }\end{array}$ & $\begin{array}{l}\text { Pythium } \\
\text { spp. }\end{array}$ & $\begin{array}{c}\text { Rhizoctonia } \\
\text { spp. }\end{array}$ & $\begin{array}{l}\text { C. destruc- } \\
\text { tans }\end{array}$ & $\begin{array}{c}\text { Fusarium } \\
\text { spp. }\end{array}$ & $\begin{array}{l}\text { Pythium } \\
\text { spp. }\end{array}$ & $\begin{array}{c}\text { Rhizoctonia } \\
\text { spp. }\end{array}$ \\
\hline Control & $28.3 \mathrm{a}$ & $14.8 \mathrm{ab}$ & $11.5 \mathrm{~b}$ & $17.0 \mathrm{a}$ & $16.9 \mathrm{a}$ & $20.0 \mathrm{a}$ & $9.4 \mathrm{a}$ & $12.8 \mathrm{a}$ \\
\hline 1,3-D-chloropicrin & $0.8 \mathrm{~b}$ & $9.2 \mathrm{bc}$ & $3.3 \mathrm{c}$ & $5.0 \mathrm{~b}$ & $4.4 \mathrm{~b}$ & $23.8 \mathrm{a}$ & $0.0 \mathrm{~b}$ & $4.5 \mathrm{c}$ \\
\hline RSM-mefenoxam & $5.0 \mathrm{~b}$ & $10.6 \mathrm{~b}$ & $2.5 \mathrm{c}$ & $5.6 \mathrm{~b}$ & $8.5 \mathrm{~b}$ & $13.5 \mathrm{~b}$ & $0.8 \mathrm{~b}$ & $3.8 \mathrm{c}$ \\
\hline RSM-solarization & $5.8 \mathrm{~b}$ & $2.5 \mathrm{c}$ & $25.8 \mathrm{a}$ & $0.0 \mathrm{~b}$ & $7.5 \mathrm{~b}$ & $10.8 \mathrm{~b}$ & $0.0 \mathrm{~b}$ & $1.6 \mathrm{c}$ \\
\hline Wheat-RSM & $19.3 \mathrm{a}$ & $18.1 \mathrm{a}$ & $19.4 \mathrm{ab}$ & $6.9 \mathrm{~b}$ & $19.1 \mathrm{a}$ & $20.6 \mathrm{a}$ & $1.9 \mathrm{~b}$ & $0.0 \mathrm{c}$ \\
\hline Solarization $^{z}$ & & & $\ldots$ & & $2.5 \mathrm{~b}$ & $13.8 \mathrm{~b}$ & $1.3 \mathrm{~b}$ & $8.4 \mathrm{~b}$ \\
\hline$P$ & $<0.001$ & 0.019 & $<0.001$ & 0.004 & 0.001 & 0.023 & $<0.001$ & $<0.001$ \\
\hline
\end{tabular}

${ }^{\mathrm{x}}$ Study was conducted using a randomized complete block design with four replicates, each consisting of eight trees. Values in the same column followed by the same letter are not significantly different based on the Tukey test $(P=0.05)$.

${ }^{\text {y }} \mathrm{RSM}=$ Brassica napus seed meal.

${ }^{\mathrm{z}}$ Treatment was not assessed at the CV orchard. 
Table 5. Effect of soil treatments on populations of Pratylenchus spp. (number per gram of root) recovered from roots of Gala/M26 and Golden Delicious/M7 apple at the Columbia View Research (CV) orchard, Orondo, WA and Wenatchee Valley College-Auvil Research and Demonstration (WVC) orchard, East Wenatchee, WA, respectivelyy

\begin{tabular}{lccc}
\hline Treatment $^{\mathbf{z}}$ & CV October 2002 & WVC October 2002 & WVC October 2003 \\
\hline Control & $89.1 \mathrm{a}$ & $279 \mathrm{a}$ & $621 \mathrm{~b}$ \\
1,3-dichloropropen-chloropicrin & $12.8 \mathrm{~b}$ & $51 \mathrm{~b}$ & $84 \mathrm{~d}$ \\
RSM-mefenoxam & $2.5 \mathrm{~b}$ & $56 \mathrm{~b}$ & $304 \mathrm{c}$ \\
RSM-solarization & $34.3 \mathrm{~b}$ & $73 \mathrm{~b}$ & $260 \mathrm{c}$ \\
Wheat-RSM & $6.5 \mathrm{~b}$ & $125 \mathrm{~b}$ & $567 \mathrm{~b}$ \\
Solarization & $\ldots$ & $252 \mathrm{a}$ & $1135 \mathrm{a}$ \\
$P$ & 0.009 & 0.012 & $<0.001$ \\
\hline
\end{tabular}

${ }^{y}$ Study was conducted using a randomized complete block design with four replicates, each consisting of eight trees. Values in the same column followed by the same letter are not significantly different based on the Tukey test $(P=0.05) ; \ldots=$ treatment was not assessed at the $\mathrm{CV}$ orchard.

${ }^{\mathrm{z}} \mathrm{RSM}=$ Brassica napus seed meal.

intermedium) and the WVC (P. sylvaticum) orchards, which respond differentially to RSM amendment. Proliferation of Pythium spp. populations in response to RSM amendment generally has been one order of magnitude or less in WVC orchard soil whereas, in CV orchard soil, the corresponding increase has been a minimum of two orders of magnitude (4; M. Mazzola, unpublished data).

In contrast to the $\mathrm{CV}$ orchard, growth of trees in the RSM-mefenoxam treatment did not attain levels achieved in 1,3dichloropropene-chloropicrin-fumigated soil at the WVC orchard. RSM-mefenoxam provided control of Cylindrocarpon, Pythium, and Rhizoctonia spp., and initial suppression of Pratylenchus spp., which was equivalent to that obtained in fumigated soil. However, by the end of the second growing season, root populations of Pratylenchus spp. had increased significantly for all treatments with the exception of 1,3-dichloropropene-chloropicrin fumigation. In these trials, RSM was incorporated into the soil profile to a depth of 15 to $20 \mathrm{~cm}$. Nematode suppression induced by the low-glucosinolate-content RSM is more likely a result of the nematicidal nature of nitrogenous amendments rather than production of a volatile glucosinolate hydrolysis product $(4,9,20)$; therefore, nematode populations at greater depths likely were not affected by RSM application.

The findings presented here substantiate the causal role of the identified fungal complex, at times in conjunction with the lesion nematode, as the primary incitants of replant disease in Washington (14). Control methods that adequately suppressed all elements of this pathogen complex, such as preplant fumigation and the RSM-mefenoxam treatments, significantly enhanced tree growth and yield. Likewise, methods that resulted in levels of pathogen and parasite suppression that were intermediate between the control and preplant fumigation consistently provided a correspondingly intermediate growth increment and fruit yield. Although other factors, both biotic and abiotic, may contribute to limiting the growth of apple when estab- lished on sites previously cultivated to this crop, targeting these biological factors appears to be a suitable approach to the development of nonfumigant measures for the control of replant disease.

Among treatments examined in these studies, the RSM-mefenoxam treatment possesses superior potential as an alternative to preplant fumigation for the control of replant disease. A 3-year B. napus green manure provided a level of disease control similar to that of RSM-mefenoxam. However, effective implementation of the green manure strategy required a 3-year period of lost orchard productivity, whereas the RSM-mefenoxam treatment was executed in a time frame characteristic of that required for orchard fumigation. As a result of the time required for implementation, application of the RSM-mefenoxam treatment will be a more feasible method, from an economic perspective, compared with the use of a $B$. napus green manure, for the control of ARD. In the current studies, application of seed meal to plots receiving the RSM-mefenoxam was conducted in the autumn prior to planting the following spring. It is during this same period that growers typically conduct soil fumigation, suggesting that the alternative control procedure will be compatible with current orchard management practices.

\section{LITERATURE CITED}

1. Angus, J. F., Gardner, P. A., Kirkegaard, J. A., and Desmarchelier, J. M. 1994. Biofumigation: isothiocyanates released from Brassica roots inhibit growth of the take-all fungus. Plant Soil 162:107-112.

2. Brown, P. D., and Morra, M. J. 1997. Control of soil-borne plant pests using glucosinolatecontaining plants. Adv. Agron. 61:167-231.

3. Browne, G., Connell, J., McLaughlin, S., Lee R., Schneider, S., and Trout, T. 2004. Potential of chemical and non-chemical approaches for managing Prunus replant disease. Pages 7.144.5. in: Proc. Annu. Int. Res. Conf. Methyl Bromide Alternatives and Emissions Reductions, San Diego, CA.

4. Cohen, M. F., Yamasaki, H., and Mazzola, M. 2005. Brassica napus seed meal soil amendment modifies microbial community structure, nitric oxide production and incidence of Rhizoctonia root rot. Soil Biol. Biochem. 37:1215-1227.

5. Covey, R. P., Jr., Benson, N. R., and Haglund, W. A. 1979. Effects of soil fumigation on the apple replant disease in Washington. Phytopathology 69:684-686.

6. Gardner, P. A., Angus, J. F., Pitson, G. D., and Wong, P. T. W. 1998. A comparison of six methods to control take-all in wheat. Aust. J. Agric. Res. 49:1225-1240.

7. Gu, Y.-H., and Mazzola, M. 2003 Modification of fluorescent pseudomonad community and control of apple replant disease induced in a wheat cultivar-specific manner. Appl. Soil Ecol. 24:57-72.

8. Johnson, A. W., Golden, A. M., Auld, D. L., and Sumner, D. R. 1992. Effects of rapeseed and vetch as green manure crops and fallow on nematodes and soil-borne pathogens. J. Nematol. 24:117-126.

9. Koenning, S. R., Edmisten, K. L., Barker, K. R., Bowman, D. T., and Morrison, D. E. 2003. Effects of rate and timing of application of poultry litter on Hopolaimus columbus on cotton. Plant Dis. 87:1244-1249.

10. Lewis, J. A., and Papavizas, G. C. 1971. Effect of sulfur-containing volatile compounds and vapors from cabbage decomposition on Aphanomyces euteiches. Phytopathology 61:208-214.

11. Mai, W. F., and Abawi, G. S. 1981. Controlling replant disease of pome and stone fruits in northeastern United States by preplant fumigation. Plant Dis. 65:859-864.

12. Manici, L. M., Lazzeri, L., and Palmieri, S. J. 1997. In vitro fungitoxic activity of some flucosinolates and their enzyme-derived products toward plant pathogenic fungi. J. Agric. Food Chem. 45:2768-2773

13. Mazzola, M. 1997. Identification and pathogenicity of Rhizoctonia spp. isolated from apple roots and orchard soils. Phytopathology 87:582-587.

14. Mazzola, M. 1998. Elucidation of the microbial complex having a causal role in the development of apple replant disease in Washington. Phytopathology 88:930-938.

15. Mazzola, M., Andrews, P. K., Reganold, J. P., and Lévesque, C. A. 2002. Frequency, virulence, and metalaxyl sensitivity of Pythium spp. isolated from apple roots under conventional and organic production systems. Plant Dis. 86:669-675.

16. Mazzola, M., Funnell, D. L., and Raaijmakers, J. M., 2004. Wheat cultivar-specific selection of 2,4-diacetylphloroglucinol-producing fluorescent Pseudomonas species from resident soil populations. Microb. Ecol. 48:338-348.

17. Mazzola, M., Granatstein, D. M., Elfving, D. C., and Mullinix, M. K. 2001. Suppression of specific apple root pathogens by Brassica napus seed meal amendment regardless of glucosinolate content. Phytopathology 91:673679.

18. Mazzola, M., and Gu, Y.-H. 2000. Impact of wheat cultivation on microbial communities from replant soils and apple growth in greenhouse trials. Phytopathology 90:114-119.

19. Mazzola, M., and Gu, Y.-H. 2002. Wheat genotype-specific induction of soil microbial communities suppressive to disease incited by Rhizoctonia solani anastomosis group (AG)-5 and AG-8. Phytopathology 92:1300-1307.

20. Papavizas, G. C. 1966. Suppression of Aphanomyces root rot of peas by cruciferous soil amendments. Phytopathology 56:1071-1075.

21. Rodríiguez-Kabana, R. 1986. Organic and inorganic nitrogen amendments to soil as nematode suppressants. J. Nematol. 18:129135.

22. Sarwar, M., Kirkegaard, J. A., Wong, P. T. W., and Desmarchelier, J. M. 1998. Biofumigation potential of brassicas. III. In vitro toxicity of isothiocyanates to soil-borne fungal pathogens. Plant Soil 201:103-112.

23. Schneider, S., Trout, T., Browne, G., Ajwa, H., and Sims, J. 2003. Vineyard replant field trials. Pages 10.1-10.6 in: Proc. Annu. Int. Res. Conf. 
Methyl Bromide Alternatives and Emissions Reductions, San Diego, CA.

24. Slykhuis, J. T., and Li, T. S. C. 1985. Response of apple seedlings to biocides and phosphate fertilizers in orchard soils in British Columbia. Can. J. Plant Pathol. 7:294-301.

25. Smith, B. J., Kirkegaard, J. A., and Howe, G. N. 2004. Impacts of Brassica break-crops on soil biology and yield of following wheat crops. Aust. J. Agric. Res. 55:1-11.

26. Traquair, J. A. 1984. Etiology and control of orchard replant problems: a review. Can. J. Plant Pathol. 6:54-62.

27. Trout, T., Ajwa, H., and Schneider, S. 2001 Fumigation and fallowing effects on replant problems in California peach. Pages 77.1-77.6. in: Proc. Annu. Int. Res. Conf. Methyl Bromide Alternatives and Emissions Reductions, San Diego, CA.

28. Warton, B., Matthiessen, J. N., and Shackleton, M. A. 2003. Cross-enhancement: enhanced biodegradation of isothiocyanates in soils previously treated with metham sodium. Soil Biol. Biochem. 35:1123-1127. 